\title{
Sarus Ferenc*
}

\section{Ágyúnaszádok a Jangcén (1860-1949)}

A 6380 km-es Jangce Ázsia 1. számú, és a világ 3. leghosszabb folyója. Kínai elnevezése Cháng Jiāng (Hosszú folyó), a kínaiak csak a legalsó - Nanjing és Shanghai közötti 435 km-es - szakaszát hívják Jangcének. A folyó a Tibeti-fennsíkról ered, majd keresztülhalad több kínai tartományon, míg végül a Kelet-kínai-tengerbe torkollik. Hosszú szakaszon hajózható még tengeri hajók számára is, egészen Hankow ${ }^{1}$ városáig, amely 1133 km-re fekszik a torkolattól, a folyami hajók pedig további 600 km-rel feljebb képesek normál körülmények között eljutni lchang (Yichang) városáig. Kedvező vízállások esetén a felhajózás egészen Suifu-ig lehetséges, amely még további 1000 km-el feljebb fekszik a folyó torkolatától. A legnehezebben hajózható szakaszt a 21. század kezdetéig a Három-szurdok jelentette, amely a folyó mentén, az Ichang feletti területen kezdődik.

A nagyhatalmak közül Nagy-Britanniának az első ópiumháború (1839-1842) megnyerésével sikerült kikényszeríte-

\section{1. ábra. A Jangce Tibetben, a Dzsürhen-hegységben ered, és $6380 \mathrm{~km}$ áramlás után a Kelet-kínai-tengerbe torkollik (Forrás: Demis web map)}

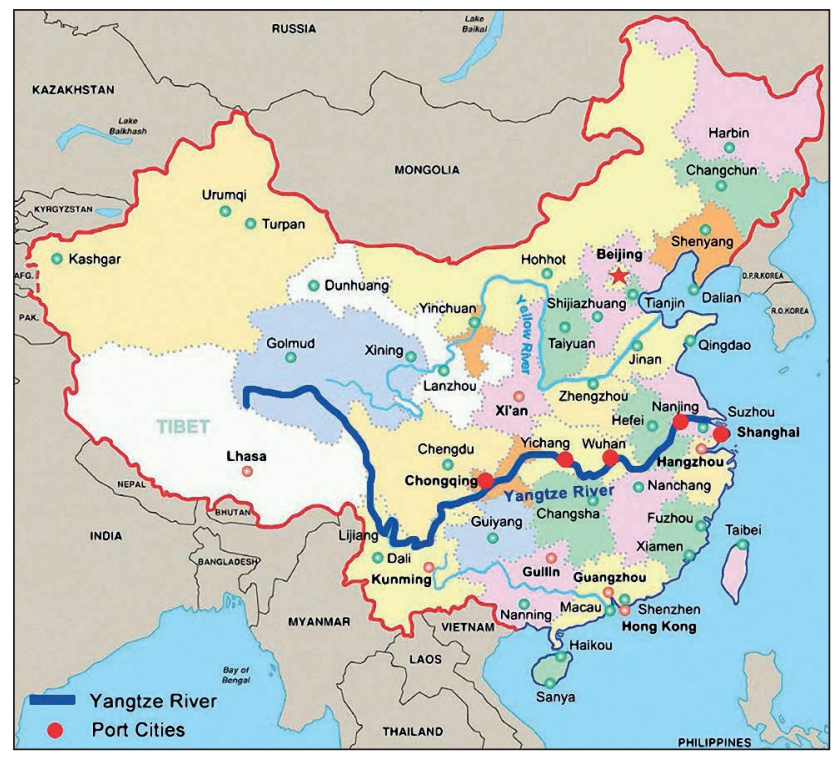

ÖSSZEFOGLALÁS: A hatalmas Jangce folyó már évezredek óta a kínai gazdaság egyik fő ütőere. Számos fontos nagyváros terül el mellette napjainkban is. Az alábbi írás a 19. század második felétől a II. világháborúig azt a kilenc évtizedet kívánja bemutatni, amely során a korabeli nagyhatalmak ún. ágyúnaszád-diplomácia alkalmazásával érvényesítették az érdekeiket a félgyarmati sorban lévő Kínával szemben.

KULCSSZAVAK: Kína, folyami hadihajók, Jangce, K.u.K. haditengerészet, ágyúnaszád nie a kínai felségvizekre történő behatolást. Az 1842-ben az Egyesült Királyság és Kína által aláírt nankingi szerződést 1858-ban a tiensini egyezmény követte, amelyet Nagy-Britannia mellett kiterjesztettek a többi nagyhatalomra (az Amerikai Egyesült Államokra, Franciaországra és a cári Oroszországra) is. Ezzel Kínában kezdetét vette nyolc évtizednyi nagyhatalmi jelenlét. A Jangce még napjainkban is a kínai gazdaság egyik fő ütőere, a birtoklása létfontosságú volt a nagyhatalmak számára is, hogy hasznot húzhassanak Kína félgyarmati státuszából.

\section{A JANGCE ÖRJÁRATOK KEZDETE}

A nagyhatalmak kivétel nélkül az „ágyúnaszád-diplomáciához" fordultak, hogy megvédjék érdekeiket az újonnan szerzett területeik felett. Ágyúnaszád-diplomácia olyan külpolitikai irányvonalat jelent, amely során az erősebb hatalom haditengerészeti egységek demonstratív bevetésével próbálja rákényszeríteni az akaratát a szemben álló félre, akár nyílt fegyveres konfliktust is kilátásba helyezve, amennyiben a követelései nem teljesülnének. A folyóra küldött hadihajók jelentették a zálogát annak, hogy az európai kereskedők és misszionáriusok nyugodtan tevékenykedhessenek, egyúttal féken tartották a kalózkodást is.

1861-re Nagy-Britannia és az Egyesült Államok hadihajói már elérték Hankow kikötőjét, 1863-ban pedig megjelentek a franciák is. 1871-re a Brit Királyi Haditengerészet (Royal Navy) - a felső Jangcét kivéve - már bázisokat épített és ágyúnaszádokat telepített a folyó mentén minden, az egyezményben megnevezett kikötőben. 1874-ben az Egyesült Államok USS ASHUELOT nevű hadihajója, Ichang városánál elérte a felső Jangcét is. Ahogy Kínában a központi hatalom (a Csing-dinasztia) egyre jobban elveszítette az irányítást az ország felett, a nagyhatalmak egyre jobban érvényesíteni tudták érdekeiket. 1900-ra már a brit ágyúnaszádok is elérték a felső Jangcét, majd ugyanezt 1901-ben a franciák is megtették. 1858-tól egészen 1941-ig ezt a 2700 km-re kiterjedő vízi úthálózatot elsősorban a nagyhatalmak ágyúnaszádjai tartották felügyeletük alatt, alkalmasint kiegészülve a kínai császárok és hadurak hajóival. Hankow városa, előnyös természetes fekvésének köszönhetően a folyami ágyúnaszádok központi állomáshelyévé nőtte ki magát. Az Egyesült Államok a polgárháború hatá-

ABSTRACT: The mighty Yangtze river has been the main artery of the Chinese economy for centuries. Even today there have been numerous important cities along it. The current article would like to show that almost 100 years when the great powers tried to enforce their will on China through gunboat policy.

KEY WORDS: China, river gunboats, Yangtze, Imperial and Royal Navy, gunboat 
sára időlegesen megszűntette a tevékenységét a Jangcén, de a konfliktus lezárultával hamarosan visszatért két egységgel, majd a 20. század fordulójától egyre erősebben éreztette jelenlétét a folyón. A franciák is folyamatosan növelték jelenlétüket, Nagy-Britannia mellett, a Háromszurdok feletti szakaszon ők is jelentősebb erőket tartottak fent. 1901-ben a császári Németország első ágyúnaszádjai is megjelentek a Jangcén, amelyek a folyó alsó szakaszán teljesítettek szolgálatot. A németek alapvetően Tsingtao-ra (Qingdao) koncentrálták a jelenlétüket. Japán az 1894-95ös kínai-japán háború megnyerésével szerzett kereskedelmi jogokat, majd 1903-tól kezdve már Hankow és Shanghai között japán ágyúnaszádok is biztosították a folyót. $A z$ Osztrák-Magyar Monarchia KAISERIN UND KÖNIGIN MARIA THERESIA nevű páncélos cirkálója 1901. május 27. - június 05. között tartózkodott Hankow városában, akkoriban ez volt a legnagyobb hadihajó, amely ilyen messzire felhatolt a folyón.

1911-ben forradalmi hullám söpört végig Kínán, ebben több kikötőváros is érintett volt, így Hankow, Nanking (Nánjīng), Shanghai (Shànghăi) is. 1911 októberében a helyzet annyira elmérgesedett Hankowban, hogy összesen 20 darab ágyúnaszád vigyázta a nagyhatalmi érdekeket².

$A z$ I. világháború kitörésével - mivel Kína semleges ország volt - a helyzet erősen megváltozott. A hadviselő felek ágyúnaszádjait vagy internálták, vagy kimenekítették az országból. Egyedül az Egyesült Államok biztosította a nagyhatalmi érdekeket 5 db ágyúnaszáddal 1917 áprilisáig, amikor, a hadba lépése miatt szintén internálták a hajóit. Az I. világháború lezárultával - Németországot, az Osztrák-Magyar Monarchiát és Oroszországot kivéve - a nagyhatalmak visszatértek a Jangcéra.

\section{AZ ÖRJÁRAT ARANYKORA}

1919-re Kínában gyakorlatilag széthullott a központi kormányzat, a nagyhatalmak pedig egyre aktívabban szóltak bele a belügyekbe és erővel tartották fenn a rendet a folyó mentén és a kikötővárosokban. A brit és az amerikai erők egyre összehangoltabban léptek fel. Az 1920-as évektől kezdve a Csang Kaj-Sek vezette Kuomintang (Kínai Nacionalista Párt) megkezdte az ország egyesítését, amely egyben a kínai nacionalizmus megerősödéséhez és az idegenekkel szembeni gyűlölet fokozódásához vezetett. 1927 januárjában a kínai erők bevették Hankow városát. Összesen $35 \mathrm{db}$ ágyúnaszád tartotta fenn a rendet a nagyhatalmak által ellenőrzött folyó menti területeken ${ }^{3}$, ekkora erő jelenléte elég volt ahhoz, hogy a kedélyek lecsillapodjanak.

Időközben a Kuomintang soraiból kiváltak a kommunisták, így a nemzeti erők új ellenséggel kerültek szembe, amely elvonta a figyelmet a nagyhatalmak jelenlétéről. Japán egyre gyorsuló ütemben szállta meg a Kína körüli területeket, majd 1937-től megtámadta Észak-Kínát is, és elfoglalta Pekinget. 1937-től a japánok agresszívabb politikát folytattak a többi nagyhatalommal szemben is, több esetben tüzet nyitottak a nyugati ágyúnaszádokra, illetve egy légitámadásban4 elsűllyesztették az Egyesült Államok USS PANAY ágyúnaszádját. 1938-ra az ágyúnaszádok többsége már csak helyi szolgálatot látott el, mert a japánok egyre jobban szigorították a szabad mozgásuk feltételeit és a kereskedelmet is igyekeztek gátolni.

A II. világháború kitörésekor a brit ágyúnaszádok egy része visszatért Európába, a Kínában maradt egységeket pedig leszerelték. 1940-re a briteknek csak 4 ágyúnaszádjuk maradt a Jangcén, míg 1937-ben még 13 állt szolgálatban. 1941-re az amerikai hajók többsége is elhagyta a fo- lyót, egy részük a Fülöp-szigetekre hajózott át, csak 2 db ágyúnaszád maradt, az egyik Shanghaiban, a másik pedig a Felső-Jangcén. A Pearl Harbor-i bombázás után az Egyesült Államok és Nagy-Britannia is hadban állt Japánnal, a Shanghaiban maradt két ágyúnaszádot a japánok elfoglalták (USS WAKE), illetve elsüllyesztették (HMS PETEREL).

\section{AZ ŐRJÁRATOK VÉGE}

Japán veresége után a nyugati hatalmak egy rövid időre még visszatértek a Jangcére, de már nem vezettek rendszeres őrjáratokat. Kína belsejét teljesen feldúlta a kommunisták és a nemzeti erők között folyó polgárháború. 1949re a belviszályból a kommunisták kerültek ki győztesen, amelynek a következményeként a nagyhatalmak sem voltak többé szívesen látott vendégek az országban. A legutolsó incidensre 1949. április 20-án került sor, amikor a brit HMS AMETHYST Shanghai-ból Nanking-be tartott, hogy az ottani brit konzulátust védelmezze. A kommunisták parti ütegeikkel rálőttek a hajóra és eltalálták az ágyúnaszád kormányállását, ezután a hajó partra futott, ahol további 50 találat érte. A hajó kapitánya halálos sebet kapott, az első tiszt a legénység nagy részét sikeresen partra tette a folyó nemzeti erők által birtokolt oldalán, majd 2 nappal később sikeresen lehúzta a partról a naszádot és horgonyt vetett a kommunisták ágyúinak lőtávolságán kívül. Az egység tíz héten keresztül vesztegelt mintegy 150 km-re Shanghai-tól, közben a diplomáciai tárgyalások sorozatosan eredménytelennek bizonyultak. Végül, július 30-án, az éjszaka közepén a hajó kitört szorongatott helyzetéből. Számtalan parti üteg mellett haladt el szerencsésen, és még egy fatörzsekből emelt torlaszt is sikeresen áttört, majd biztonságban elérte Woosung-ot.

\section{AZ ÁGYÚNASZÁDOK TÍPUSA NEMZETEK SZERINT}

Hankow fölött csak a folyami hajók számára volt alkalmas a Jangce vize a közlekedésre, ezért - az üzemeltető nemzetektől függetlenül -, az ágyúnaszádok építésekor számos irányelvet mindenkinek be kellett tartania, ha a folyó felső szakaszait is el szerette volna érni. A kifejezetten folyami szakaszokra jellemzően két hajócsavarral meghajtott, lapos hajófenekű egységeket építettek, amelyeknek a merülése is kellőképpen sekély volt. Külön problémát jelentett a Három-szurdok, amelyen áthajózni csak jól manőverezhető, nagy géperejü egységekkel lehetett.

Ezeket a hadihajókat tulajdonosaiknál jóval gyengébben felszerelt ellenséges csapatok ellen tervezték, akik alig rendelkeztek modern értelemben vett fegyverzettel. Ezért e hajókat szinte alig borította páncélzat és a fő fegyverzetük sem volt túl erős, de az alkalmasint még karddal és lándzsával rohamozó ellenség ellen ezek a modern gyorstüzelő fegyverek is elég elrettentő erőt képviseltek.

\section{Királyı Haditengerészet (Royal Navy)}

Az első, kifejezetten erre a célra épített ágyúnaszádok a Jangcén a HMS WOODCOCK és a HMS WOODLARK voltak. Mindkét hajót Skóciában építették, majd darabokban szállították Shanghaiba, ahol az egyes elemeket összeszerelték. Ezek az egységek voltak az első olyan ágyúnaszádok, amelyek elérték a Felső-Jangcét. Bár fegyverzetük gyenge volt és nem rendelkeztek nagy teljesítménnyel, ezt 


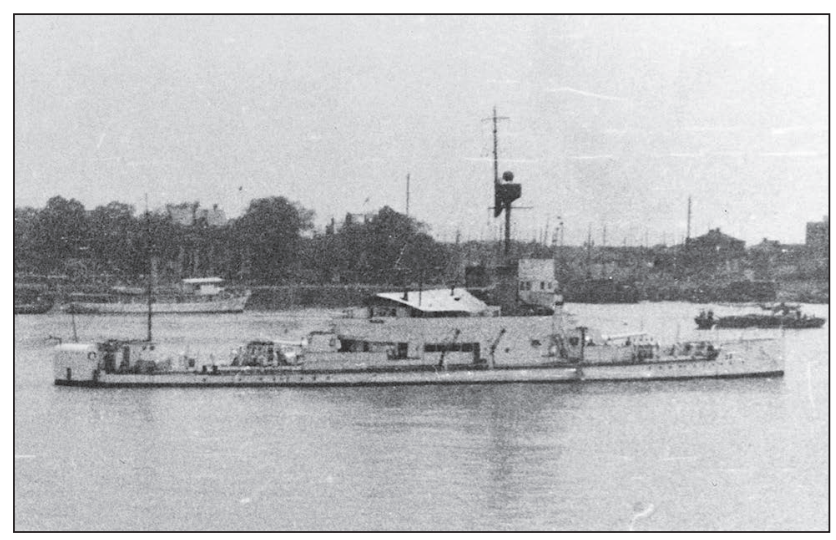

2. ábra. A HMS BEE 1920-tól 1938-ig a brit Jangce-flotta zászlóshajójaként őrjáratozott (Forrás: naval-history.net)

a hátrányt némiképp ellensúlyozta csekély merülésük, és jó manőverező képességük. Ezt az osztályt egy módosított széria követte három egységgel: HMS TEAL, HMS MOORHEN, HMS WIDGEON. Ezek a hajók leginkább nagyobb méretükben különböztek az előd típustól, de még mindig eléggé szegényes kialakításúak voltak; a fedélzeten pl. nem alkalmaztak elektromos áramot. 1910-re javult a helyzet, és a brit hajókat elektromos generátorral és vezeték nélküli távíróval is felszerelték.

Az Insect osztályú ágyúnaszádok, egy kivételével mind szolgáltak a Jangcén. Eredetileg az egységek bevetését a Dunára tervezték az osztrák-magyar monitorok ellen, ezért valamennyit 6 hüvelykes $(15,24 \mathrm{~cm})$ ágyúkkal szerelték fel. A brit hajók, elődeiknél már nagyobb merüléssel rendelkeztek, emiatt csak megfelelően magas vízállás esetén voltak képesek felhajózni a Felső-Jangcére. Az 1920-as években tovább javították a járművek kormányozhatóságát, hogy könnyebben meghajózhassák a Három-szurdok veszélyes szakaszát. Egészen az 1920-as évek végéig ezek az egységek jelentették a Jangcén lévő brit erők gerincét, ekkor nagyobb és modernebb típusokkal kezdték leváltani az Insect osztályt megelőző egységeket. A II. világháború kitöréséig összességében még öt új brit ágyúnaszád érkezett a Jangcére: a HMS PETEREL, a HMS GANNET, a HMS FALCON, a HMS SANDPIPER és a HMS SCORPION. A Királyi Haditengerészet 1940 januárjában beszüntette Kínában a rendszeres tevékenységét, ekkorra az ágyúnaszádok többsége már elhagyta a kínai felségvizeket.

\section{Az Egyesült ÁlLamoK Haditengerészete (United States Navy)}

Az amerikaiak két első egysége, amely az amerikai polgárháború (1861-1865) után visszatért a Jangcére, a USS MONOCACY és USS ASHUELOT volt. Mindkettő a háborúból megmaradt lapátkerekes hajó volt. A következő bővítési hullám 1900-ban következett be, ekkor több, a spanyoloktól zsákmányolt egység került át a Jangcére ${ }^{5}$. Bő két évtizedig ezek az egységek jelentették az amerikai jelenlétet: az USS ELCANO, az USS QUIROS, az USS SAMAR, és az USS VILLALOBOS. Ezeket a spanyol hajókat támogatta még a nagyobb méretű USS HELENA és alkalmanként a USS WILMINGTON, ez a két hajó számított a Jangcén a legnagyobbnak. Ehhez a flottához 1914-ben csatlakozott a USS MONOCACY (második ezen a néven) és a USS PALOS. Ez a két hajó nem volt túl népszerű a legénység körében, ugyanis eredetileg a Nagy-tavakra tervezték őket, így manőverezésük gyenge, kialakításuk a személy-

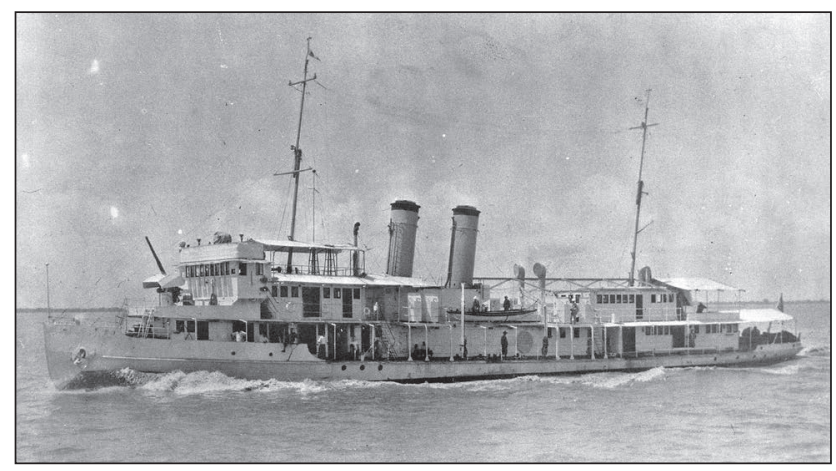

3. ábra. A USS PANAY-t a japánok 1937. december 12-én egy légi támadás során elsüllyesztették (Forrás: combinedfleet.com)

zet számára kényelmetlen volt. Az 1920-as évek végére a meglévő ágyúnaszád-flotta már cserére szorult, ekkor az Egyesült Államok kormánya hat új egység építését rendelte el, amelyek már Shanghaiban épültek, és 1927-ben léptek szolgálatba. Az öreg hajók többségét vagy kivonták a hadrendből, vagy hazarendelték, utolsónak az USS PALOS maradt. A hat új amerikai ágyúnaszádot párokban adták át. Az első páros az USS GUAM és az USS TUTUILA volt, amelyeket 1928-ban, a némileg nagyobb méretű USS OAHU és az USS PANAY követett. A legutolsó két hajót az USS LUZON-t és a USS MINDANO-t még nagyobbra építették, ezzel gyakorlatilag már vízre bocsátásuk pillanatában alkalmatlanok voltak a Hankow fölötti vizeken való járőrözésre. Ezek az egységek jó szolgálatot tettek, de a USS PANAY 1937-es elsüllyesztése után, ahogy a japánok egyre jobban korlátozták kereskedelmüket a rivális nagyhatalmakkal, az amerikai gazdasági érdekeltségek látványosan visszaszorultak Kínában. Az ágyúnaszádok többsége áthajózott a Fülöp-szigetekre. Az USS GUAM-ot a japánok elkobozták ${ }^{6}$, az USS TUTUILA-t pedig átadták a kínai nacionalista erőknek. Ezzel lényegében véget ért az amerikai jelenlét.

\section{A Császári Japán Haditengerészet (Dal-Nippon Teikoku Kaigun KoukUU-tai)}

A japánok viszonylag későn érkeztek a Jangcére, számukra az orosz-japán háborúban (1904-1905) aratott győzelem hozta meg a Kínában történő érdekérvényesítést. Az első három ágyúnaszádjuk: az IJN UJI, az IJN FUSHIMI, az IJN SUMIDA még Nagy-Britanniában épült. Közülük az IJN FUSHIMI elég erős volt ahhoz, hogy felhajózhasson a Felső-Jangcéra. Két további egység érkezett az I. világháború kitörésekor: az IJN TOBA és az IJN SAGA. Az 1920as évek végén őket követte a Seta osztály négy egysége: az IJN SETA, az IJN KATADA, az IJN HONZU, és az IJN HIRA. Az IJN ATAKA szolgált a Japán 11. flotta parancsnoki hajójaként, bár a mérete csak a folyó alsó szakaszán tette lehetővé a bevetéseket. Az 1930-as években további két hajóval, az Atami osztály érkezett: az IJN FUTAMI és az IJN ATAMI. Ezen egységek kellően sekély merüléssel bírtak a Tung-ting (Dòngtíng Hú) tavi bevetésekhez és a Xiang folyón történő hajózáshoz. 1931-ben a kis méretű IJN SUMIDA érkezett a folyóra, hogy a Jangce középső és felső szakaszán őrjáratozzon. A második kínai-japán háború (19371945) során rombolók és könnyű cirkálók is támogatták a japán szárazföldi csapatokat, miközben a sereg Shanghaiból Hankow felé menetelt. A japánok a Il. világháborúban még további újonnan épített vagy zsákmányolt egységekkel egészítették ki a Jangce-flottájukat. A háború végén 


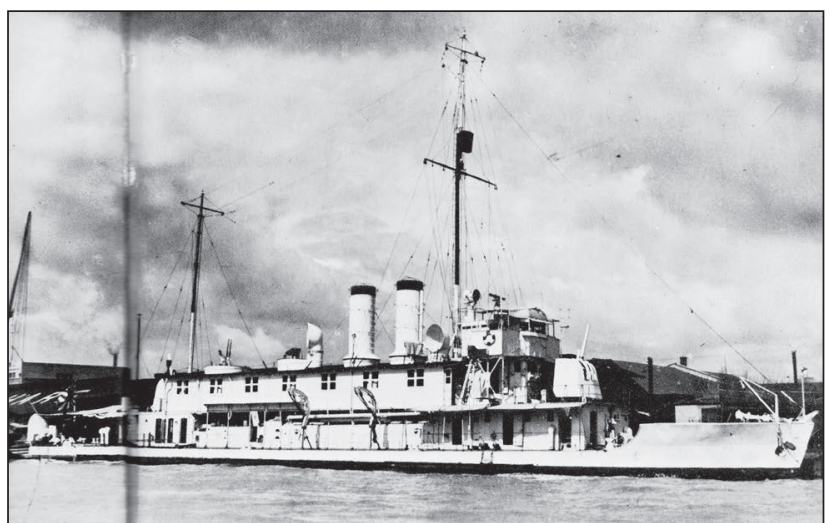

4. ábra. A japán IJN SETA egység (Forrás: Wikipedia)

ezek a hajók jellemzően megsemmisültek, a megmaradtakat átadták a kínai nemzeti erőknek.

\section{A Német Császári Haditengerészet (KaISERLiche Marine)}

A németek 1897-ben jelentek meg Kínában, de kezdetben nem a Jangcéra koncentráltak, mivel a fő érdekszférájuk Tsingtao körül összpontosult, a Sárga-tengeren. Ugyanakkor az SMS TIGER és SMS LUCHS nevű tengeri ágyúnaszádok egészen Hankowig felhatoltak a folyón, az SMS ILTIS és SMS JAGUAR nevű egységek pedig a folyó alsó szakaszán őrjáratoztak. A Jangcén csak a SMS VORVARTS nevű átalakított gőzös, és a SMS VATERLAND ágyúnaszád teljesített egész évben szolgálatot. Az SMS VORVARTS-ot 1909-ben kivonták a szolgálatból, és helyette megépítették az SMS OTTER-t Shanghaiban. A kínaiak az I. világháború kitörése után a még a Jangcén tartózkodó egységeket internálták, vagy elsüllyesztették.

\section{A Francia Haditengerészet (Marine nationale)}

Bár a franciák tengeri egységekkel már 1860-tól jelen voltak a Jangcén, de csak 1900-ban alakították ki első flottillájukat. Az Argus osztály két egységből állt: az ARGUS-ból és a VIGILANTE-ból, amelyeket Nagy-Britanniában építettek, majd Hong Kongban (Hongkong) szerelték össze. Az OLRY 1901-ben érkezett Kínába, és egészen 1909-ig a Felső-Jangcén teljesített szolgálatot. A franciáknak egészen 1922-ig nem volt állandó hajójuk a folyó alsó szakaszán; abban az évben a Doudart de Lagrée osztály két hajóját vezényelték ide: a DOUDART de LAGRÉE-t és a BALNY-t, amelyek egészen a II. világháborúig itt szolgáltak. Szintén 1922-ben érkezett meg az ALERTE nevü sloop, amelynek egészen az 1936-os visszahívásáig Hankow volt a bázisa. 1927-ben érkezett meg a francia Jangce-flottilla zászlóshajója, a FRANCIS GARNIER, amelyet a II. világháború kitörése után Francia Indokínába vezényeltek.

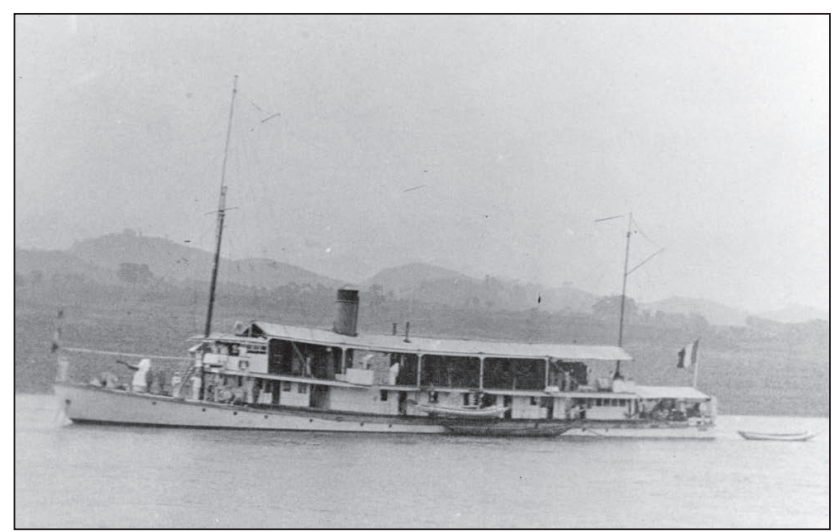

6. ábra. A DOUDART de LAGRÉE 1922-től a II. világháborúig szolgálta a francia Jangce-flottát (Forrás: navypedia.org)

5. ábra. Az SMS ILTIS 1899. február 6-án csatlakozott a Német Császári Haditengerészet Jangce-flottájához. Legénysége 1914-ben, Kiaocsou kikötőjében elsüllyesztette (Forrás: www.history.navy.mil)

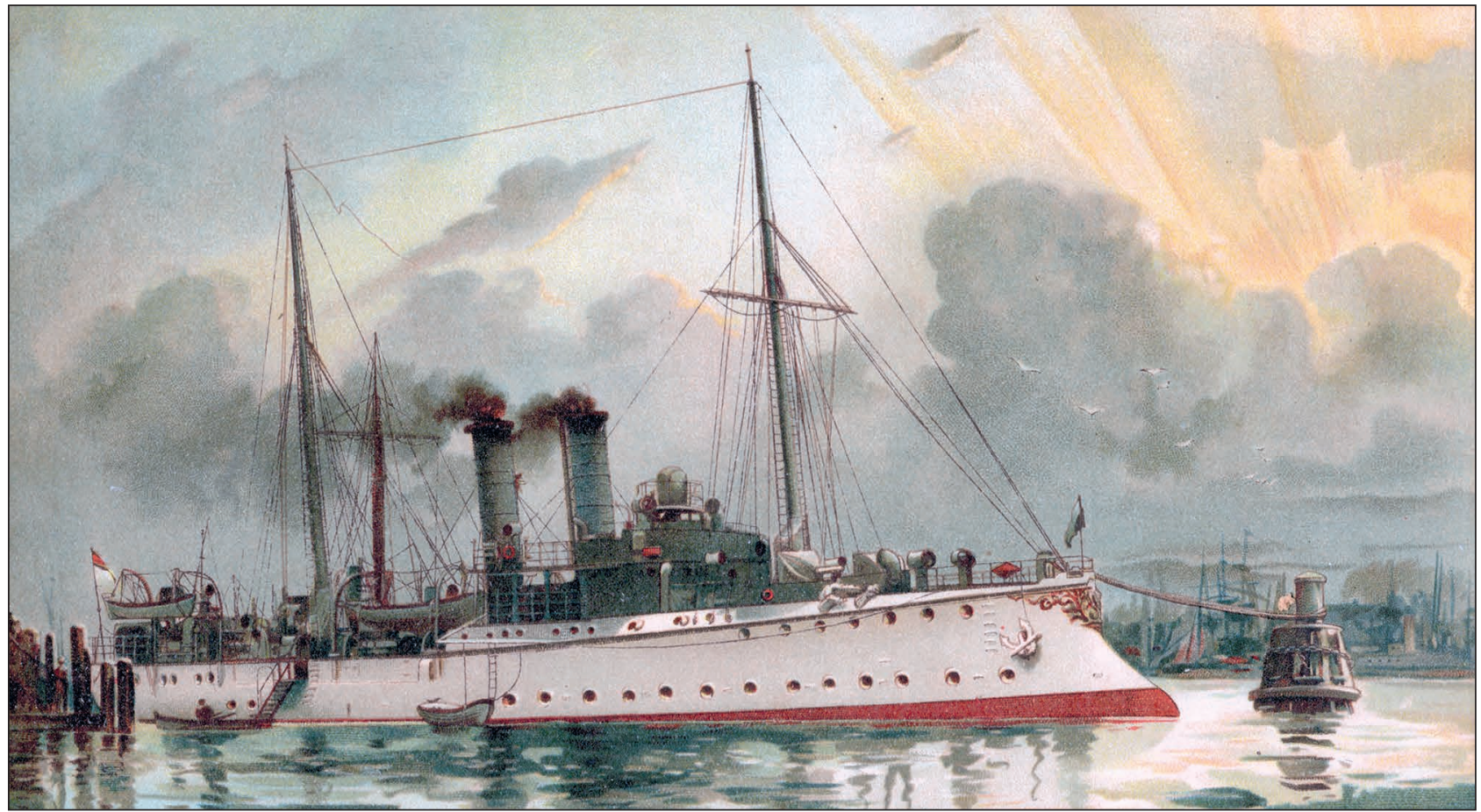




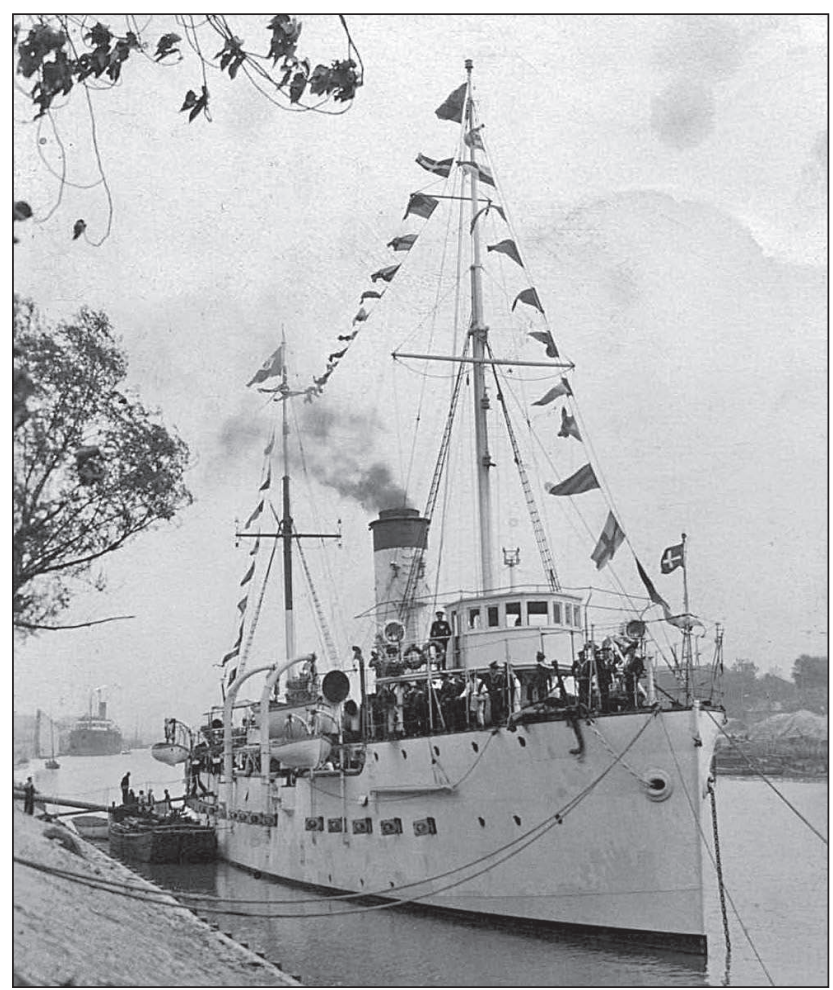

7. ábra. Az olasz LEPANTO ágyúnaszádot 1938-ban rendelték Sanghajba, végül 1943-ban legénysége elsüllyesztette (Forrás: Hajime Fukaya)

\section{Az Olasz Király Haditengerészet (Regia Marina)}

A Jangce mérsékelten tartozott az Olasz Királyság érdekszférájába, csak a két világháború között vezényeltek egységeket a folyóra. 1920-ban jelent meg a SEBASTIANO CABOTO, amely nagy merülése miatt csak időszakosan tudott felhajózni a folyón. Az egységet a II. világháború kitörése előtt rendelték vissza Olaszországba. Két másik olasz ágyúnaszád is csak alkalmi vendégnek számított a Jangcén: az ERMANNO CARLOTTO és a LEPANTO. Végül 1938-ban Sanghajba irányították, majd 1943-ban mindkettőt elsüllyesztették, amikor Olaszország kilépett a háborúból. Később a japánok kiemelték a hajókat, amelyek a háború után a kínai nemzeti erőkhöz kerültek.

\section{Az Osztrák-Magyar Monarchia Császári és Királyı haditengerésZete (KaISERLICHE Und KöNIGLICHe KRIEGSMARINE)}

Az Osztrák-Magyar Monarchia nem rendelkezett állandó jelenléttel a Jangcén, de időnként egyes hadihajói érintették a Kelet-kínai tenger torkolatnál fekvő Sanghaj kikötőjét, néhány alkalommal pedig feljebb is hatoltak a folyón. Több ízben vettek részt zavargások elfojtásában, illetve partraszálló különítményeket indítottak a rend helyreállítására a szárazföld belsejébe is. A Monarchia nem építtetett külön folyami ágyúnaszádokat, mivel a gazdasági érdekeltségei elsősorban Csingtao (Qingdao) városa köré összpontosultak. Szükség esetén a mélytengeri egységeket küldték fel a folyó mentén, ami 1133 km-re a torkolattól, Hankow városáig tette lehetővé számura a bevetéseket. Az alábbi egységek fordultak meg a Jangcén: az SMS PANTHER torpedócirkáló, az SMS LEOPARD torpedócirkáló, az SMS KAISER FRANZ JOSEF I védett cirkáló, az SMS KAISERIN ELISABETH védett cirkáló, az SMS KAISERIN und KÖNI-

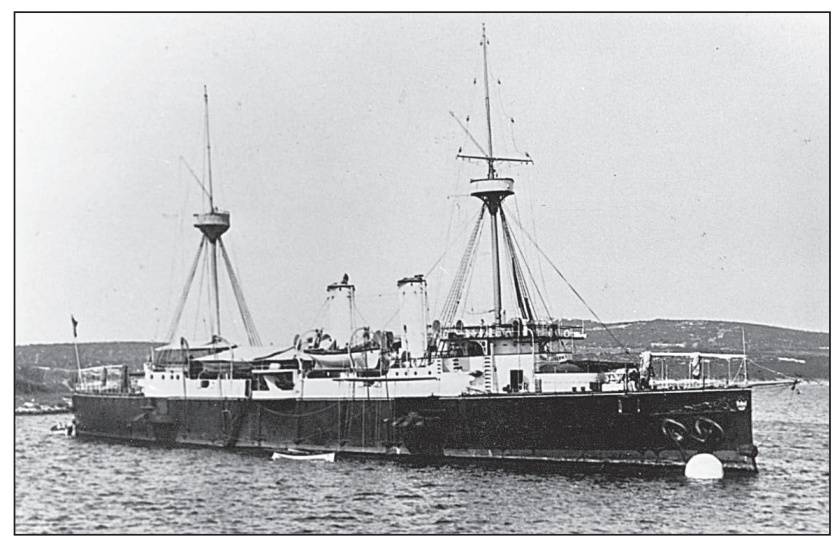

8. ábra. Az Osztrák-Magyar Monarchia 4000 tonnás védett cirkálója, az SMS KAISER FRANZ JOSEPH I

(Forrás: history-navy.mil)

GIN MARIA THERESIA páncélos cirkáló, az SMS ZENTA védett cirkáló, az SMS ASPERN védett cirkáló, az SMS SZIGETVÁR ${ }^{7}$ védett cirkáló. Hankow városáig 9 alkalommal jutottak el a Monarchia hadihajói; az SMS ZENTA, az SMS KAISERIN und KÖNIGIN MARIA THERESIA, az SMS ASPERN, valamint az SMS LEOPARD egyszer, az SMS KAISER FRANZ JOSEF I. kétszer, az SMS KAISERIN ELISABETH pedig háromszor fordult meg a település partjainál. Jellemzően csak néhány napot, maximum egy hetet töltöttek el itt az egységek, magán a Jangcén sem tartózkodtak egy hónapnál tovább. (Ez alól csak Sanghaj kikötője jelentett kivételt, ahol előfordult hosszabb tartózkodás.)

\section{A cári Oroszország Haditengerészete}

A nagyhatalmak közül legkevésbé Oroszország vette ki a részét a Jangce őrjáratból. Ennek oka, hogy területi igényeik: Mandzsúria és Kelet-Szibéria vidéke, viszonylag távol esett a Jangcétól. Az orosz-japán háború Oroszország számára kedvezőtlen befejezése szintén tovább gyengítette a cári birodalom érdekérvényesítő képességeit. Az 1911-es Hankow-i lázadások alatt a folyóra küldték a MANDZHUR ágyúnaszádjukat, de ezen kívül a Jangce térségében érdemi eseményekben nem vettek részt.

\section{9. ábra. A KOREETS, a MANDZHUR testvérhajója. A cári} Ororszország Haditengerészete a Jangce térségében érdemi harci eseményekben nem vett részt (Forrás: Архив фотографий кораблей русского и советского ВМФ)

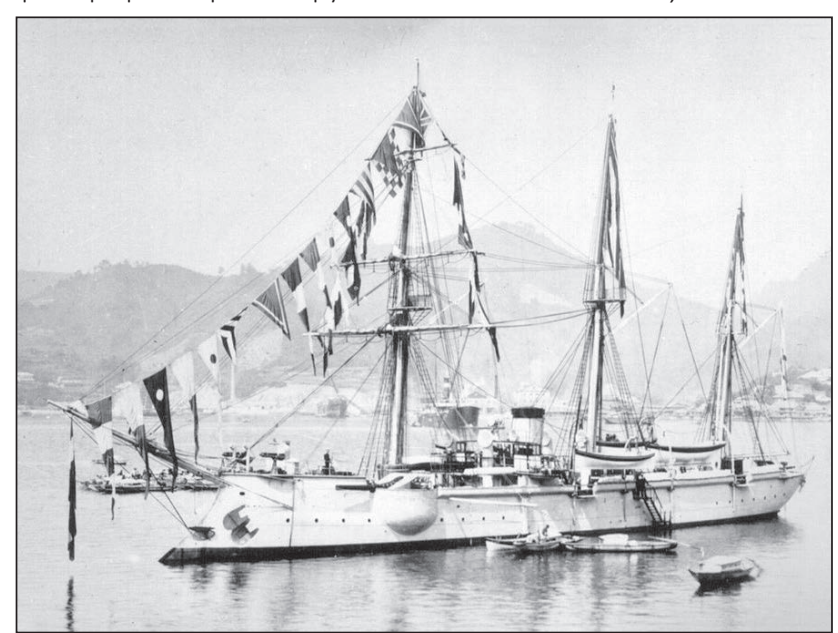


1. táblázat. Az alkalmazott hadihajók föbb adatai*

\begin{tabular}{|c|c|c|c|c|c|c|c|c|}
\hline Típus & $\begin{array}{c}\text { BEE } \\
\text { folyami } \\
\text { ágyúnaszád }\end{array}$ & $\begin{array}{c}\text { PANAY } \\
\text { folyami } \\
\text { ágyúnaszád }\end{array}$ & $\begin{array}{l}\text { SETA folyami } \\
\text { ágyúnaszád }\end{array}$ & $\begin{array}{l}\text { DOUDART } \\
\text { de LAGRÉ } \\
\text { folyami } \\
\text { ágyúnaszád }\end{array}$ & $\begin{array}{c}\text { ILTIS } \\
\text { ágyúnaszád }\end{array}$ & $\begin{array}{c}\text { KAISER FRANZ } \\
\text { JOSEF I. } \\
\text { védett cirkáló }\end{array}$ & $\begin{array}{l}\text { LEPANTO } \\
\text { ágyúnaszád }\end{array}$ & $\begin{array}{l}\text { MANDZHUR } \\
\text { ágyúnaszád }\end{array}$ \\
\hline Ország & $\begin{array}{c}\text { Egyesült } \\
\text { Királyság } \\
1915\end{array}$ & $\begin{array}{c}\text { Egyesült } \\
\text { Államok } \\
1928\end{array}$ & $\begin{array}{c}\text { Japán } \\
1923\end{array}$ & $\begin{array}{c}\text { Franciaország } \\
1909\end{array}$ & $\begin{array}{c}\text { Németország } \\
1898\end{array}$ & $\begin{array}{l}\text { Osztrák-Magyar } \\
\text { Monarchia } \\
1890\end{array}$ & $\begin{array}{c}\text { Olaszország } \\
1927\end{array}$ & $\begin{array}{c}\text { Oroszország } \\
1887\end{array}$ \\
\hline $\begin{array}{l}\text { Vízkiszorítás } \\
\text { (tonna) }\end{array}$ & 645 & 474 & 254 & 183 & 1048 & 4030,9 & 625 & 1418 \\
\hline Hosszúság (m) & $72,4 \mathrm{~m}$ & 57 & 54,86 & 54,4 & 65,2 & 103,7 & 66 & 66 \\
\hline Szélesség (m) & 11 & 8,7 & 8,23 & 6,7 & 9,1 & 14,72 & 8,7 & 10,7 \\
\hline Merülés (m) & 1,2 & 1,6 & 0,79 & 1,0 & 3,59 & 6,08 & 2,4 & 3,8 \\
\hline Teljesítmény (LE) & 2000 & 2250 & 1400 & 900 & 1378 & 8743 & 1500 & 1500 \\
\hline $\begin{array}{l}\text { Meghajtás } \\
\text { (hajócsavar) }\end{array}$ & 2 & 2 & 3 & 2 & 2 & 2 & 2 & 2 \\
\hline $\begin{array}{l}\text { Sebesség } \\
\text { (csomó) }\end{array}$ & 14 & 15 & 15 & 14 & 14,8 & 19 & 15 & 13 \\
\hline Fegyverzet & $\begin{array}{c}2 \times 6 \\
\text { hüvelykes } \\
\text { löveg, } \\
2 \times 12 \text { fontos } \\
\text { löveg, } \\
12 \times \\
\text { géppuska }\end{array}$ & $\begin{array}{l}2 \times 3 \\
\text { hüvelykes } \\
\text { löveg, } \\
8 \times \text { gép- } \\
\text { puska }\end{array}$ & $\begin{array}{c}2 \times 80 \mathrm{~mm} \text {-es } \\
\text { löveg, } \\
6 \times 7,7 \mathrm{~mm} \\
\text { géppuska }\end{array}$ & $\begin{array}{c}6 \times 37 \mathrm{~mm} \text {-es } \\
\text { löveg }\end{array}$ & $\begin{array}{c}4 \times 88 \mathrm{~mm} \text {-es } \\
\text { löveg, } \\
6 \text { géppuska }\end{array}$ & $\begin{array}{c}8 \times 15 \mathrm{~cm} \text {-es } \\
\text { löveg, } \\
9 \times 4,7 \mathrm{~cm}-\mathrm{es} \\
\text { gyorstüzelö } \\
\text { löveg, } \\
2 \times 3,7 \mathrm{~cm}-\mathrm{es} \\
\text { szórólöveg, } \\
2 \times 7 \mathrm{~cm}-\mathrm{es} \\
\text { csónaklöveg }\end{array}$ & $\begin{array}{c}2 \times 4 \\
\text { hüvelykes } \\
\text { löveg, } \\
1 \times 3 \\
\text { hüvelykes } \\
\text { légvédelmi } \\
\text { löveg, } \\
2 \text { géppuska }\end{array}$ & $\begin{array}{c}2 \times 203 \mathrm{~mm} \text {-es } \\
\text { löveg, } \\
1 \times 152 \mathrm{~mm} \text {-es } \\
\text { löveg, } \\
4 \times 107 \mathrm{~mm} \text {-es } \\
\text { löveg, } \\
1 \times 63 \mathrm{~mm} \text {-es } \\
\text { löveg, } \\
2 \times 47 \mathrm{~mm} \text {-es } \\
\text { löveg, } \\
4 \times 37 \mathrm{~mm} \text {-es } \\
\text { löveg }\end{array}$ \\
\hline Legénység (fő) & $53-55$ & 59 & 59 & 66 & 130 & 444 & 66 & 179 \\
\hline
\end{tabular}

* 1 hüvelyk [in] = 2,54 [cm]; 1 font [lb] = 0,45359237 [kg].

\section{Összegzés}

A Jangce őrjáratok tökéletes példái az ún. ágyúnaszád diplomácia érvényre juttatásának. Haditechnikai-műszaki értelemben elismerésre méltó, ahogy ezek a kis méretű hadihajók képesek voltak fenntartani az idegen érdekeket egy olyan hatalmas országban, mint Kína. Természetesen ehhez szükség volt a belpolitikai instabilitásra, és a hosszú elzárkózásból eredő technikai és szemléletbeli lemaradásra is. Napjainkra a trend megváltozott, és éppen Kína kezdi az ágyúnaszád-diplomácia segítségével fokozatosan rákényszeríteni az akaratát közvetlen és távolabbi környezetére ${ }^{8}$. A 2010-es évek óta Kína egyre fokozódó ütemben fejleszti haditengerészetét, és számos flottatámaszpontot létesített a Perzsa-öböl, az Indiai-óceán és a Dél-kínai-tenger térségében. Az Amerikai Védelmi Minisztérium (Pentagon) jelentései szerint a 2020-as évek elején a kínai haditengerészet kitör a honi vizeket védelmező flotta szerepköréből és alkalmassá válik a globális bevetésekre. A jelenlegi flottafejlesztési ütemmel számolva, 2030-ra a Dél-kínaitenger „kínai belvíz” lesz.

\section{HIVATKOZOTT IRODALOM}

[1] Angus Konstam. Yangtze River Gunboats 1900-49. Osprey Publishing, 2011;

[2] Angus Konstam. Gunboats of World War I. Osprey Publishing, 2015;

[3] Veperdi András. „Az osztrák-magyar hadiflotta az elsó világháborúban I. Cirkálók” Hajózástörténeti Közlemé- nyek 2. évf, 1. szám (2007) kriegsmarine.hu/hk/ cirkalok.pdf, letöltve: 2021. 01. 07.;

[4] „KOREETS gunboats (1887)”. Elérés 2021. január 7. http://www.navypedia.org/ships/russia/ru_of_koreets. htm;

[5] Navypedia. DOUDART DE LA GRÉE river gunboat (1909) https://www.navypedia.org/ships/france/fr_of_ doudart_de_la_gree.htm;

[6] Tolley, Kemp. Yangtze Patrol. The U.S. Navy in China.

\section{JEGYZETEK}

1 Napjainkban Wuhan.

2 Országok szerinti bontásban: 6 brit, 4 német, 3 amerikai, 3 japán, 2 orosz, 1 francia, 1 osztrák-magyar (SMS KAISER FRANZ JOSEF védett cirkáló).

3 Országok szerinti bontásban: 11 brit, 10 japán, 9 amerikai, 3 francia és 2 olasz.

4 1937. december 12-én, majdnem pontosan 4 évvel a Pearl Harbor-i hadikikötő bombázása előtt.

$5 \mathrm{Az}$ 1898-as spanyol-amerikai háborúból.

6 USS WAKE néven hajózott már ebben az időben.

7 A közös K.u.K. haditengerészet hajóin szolgáló legénység egy része magyar nemzetiségű volt. Így hatalmi érdekből magyar tengerészek is eljutottak a Jangce-ra. Adataik a bécsi Kriegsarchívban (Hadilevéltárban), a K.u.K. Haditengerészet külföldi missziós feladatot teljesítő hajózó legénység lajstromában megtalálhatók (szerk.).

8 Napjainkban a Kínai Népköztársaság gazdasága az első helyen áll, népessége 1406313000 fő (2021. január 22-i adat), és a világ legnagyobb, 2270000 fős (aktív létszám) hadseregével rendelkezik (szerk.). 